\author{
LEONARDA MARIAK \\ Instytut Polonistyki i Kulturoznawstwa \\ Uniwersytet Szczeciński
}

\title{
FRAZEOLOGIZMY W KORESPONDENCJI PRYWATNEJ HENRYKA SIENKIEWICZA
}

Sienkiewiczowska epistolografia prywatna liczy 1401 listów ${ }^{1}$ adresowanych do siedmiorga członków najbliższej rodziny, czyli trzech kolejnych żon: Marii z Szetkiewiczów - 10 listów, Marii z Wołodkowiczów - 6 listów, Marii z Babskich - 600 listów, dwojga dzieci: córki Jadwigi - 92 listy, syna - Henryka Józefa - 66 listów, siostry Heleny - 64 listy oraz szwagierki - Jadwigi z Szetkiewiczów Janczewskiej - 563 listy. Obszerny i różnorodny pod względem struktury, podejmowanej problematyki i cech językowych korpus listów powstawał $\mathrm{w}$ ciągu prawie 40 lat życia pisarza ${ }^{2}$. Warto podkreślić, ze regularna, codzienna korespondencja była dla niego bardzo ważna, bowiem dostarczała informacji o najbliższych i tym samym łagodziła tęsknotę oraz brak osobistego kontaktu z rodziną.

Dla współczesnego odbiorcy korespondencja rodzinna Sienkiewicza stanowi nieocenione źródło wiedzy o mało dotąd znanych szczegółach z życia prywatnego, towarzyskiego, uczuciowego i rodzinnego pisarza, dostarcza również wielu cennych informacji na temat właściwości idiolektalnych jego języka, realizowanego poza sferą twórczości artystycznej na płaszczyźnie zachowań pragmalingwistycznych. W literaturze przedmiotu list prywatny jest traktowany jako użytkowa forma komunikacji, sytuowana pomiędzy komunikacją ustną i pisemną (Zgółkowie 1993: 114).

${ }^{1}$ Zob. Henryk Sienkiewicz, Listy. Tom II. Część pierwsza: Jadwiga i Edward Janczewscy, oprac. M. Bokszczanin, Warszawa 1996; Tom II. Część druga: Jadwiga i Edward Janczewscy, oprac. M. Bokszczanin, Warszawa 1996; Tom II. Część trzecia: Jadwiga i Edward Janczewscy, oprac. M. Bokszczanin, Warszawa 1996; Tom IV. Część pierwsza: Maria z Szetkiewiczów Sienkiewiczowa - Maria z Wołodkowiczów Sienkiewiczowa - Maria z Babskich Sienkiewiczowa (1888-1907), oprac. M. Bokszczanin, Warszawa 2008; Tom IV. Część druga: Maria z Babskich Sienkiewiczowa (1908-1913), oprac. M. Bokszczanin, Warszawa 2008; Tom IV. Część trzecia: Henryk Józef Sienkiewicz - Jadwiga Sienkiewiczówna - Helena Sienkiewiczówna - Lucjan Sieńkiewicz, oprac. M. Bokszczanin, Warszawa 2008.

${ }^{2}$ Pierwszy datowany list, zamieszczony w zbiorze pod redakcją M. Bokszczanin powstał we wrześniu 1879 roku i był adresowany do sióstr Szetkiewiczówien - ostatni list napisał Sienkiewicz do córki 14 XI 1916, dwa dni przed swoją śmiercią. 
Celem niniejszego szkicu jest analiza związków frazeologicznych ${ }^{3}$ zawartych w korespondencji prywatnej Sienkiewicza i próba odpowiedzi na pytania, jaką funkcję pełnią te struktury w przekazie listowym, rozumianym tu jako „osobisty dialog nadawcy i odbiorcy” (Lalewicz 1975: 73), a także, jakie sposoby aktualizacji frazeologizmów (innowacja/postać kanoniczna) preferował pisarz.

W ekscerpcji uwzględniono zbiór wszystkich zachowanych listów prywatnych Sienkiewicza, który zajmuje blisko 3 tys. stron druku w wydaniu zbiorowym pod redakcją Marii Bokszczanin ${ }^{4}$. Zebrany materiał liczy łącznie około półtora tysiąca idiomów i frazemów (Lewicki, Pajdzińska 1993: 311), czyli stałych i łączliwych połączeń wyrazowych. Biorąc pod uwagę objętość badanego zbioru i liczebność zebranego materiału, trzeba zauważyć, że nasycenie listów związkami frazeologicznymi jest raczej oszczędne (średnio jeden frazeologizm przypada na jeden list), co można tłumaczyć przede wszystkim nacechowaniem i nośnością stylistyczną tej warstwy słownej języka, a także różnorodnością tematyczną listów, która wymagała zastosowania szerokiej gamy środków językowych. Nie bez znaczenia jest tu również dążność Sienkiewicza do indywidualnego, nieszablonowego podejścia w kształtowaniu tworzywa językowego korespondencji adresowanej do najbliższych.

Przechodząc do analizy zebranych związków frazeologicznych ${ }^{5}$, należy zaznaczyć, że czynnikami, które miały decydujący wpływ na ich dobór, funkcję, strukturę i proweniencję była poruszana w listach tematyka, osoba adresata, a także czas, w którym list powstawał. W korespondencji z rodziną Sienkiewicz pisał o różnych sprawach - istotnych i błahych, poważnych i humorystycznych, przeważają jednak listy poufałe, pisane z uwagi na doraźne potrzeby i aktualne tematy, wpisujące się w nurt listów teraźniejszych. Znajdujemy w nich informacje dotyczące np. podróży, urządzania mieszkań, życia w Oblęgorku, polowań, przyjmowanych gości, posiłków, kwestii finansowych i zdrowotnych, wydarzeń rodzinnych i wiele innych, które razem wzięte pokazują jakim człowiekiem prywatnie miejsca pisarz poświęcił również na omówienie wydarzeniom i relacjom rodzinnym. Rozmaitość podejmowanej problematyki przekłada się na zróżnicowanie znaczeniowe zebranych frazeologizmów, które można podzielić na pięć dużych kategorii semantycznych:

1. Zdrowie i choroby

2. Podróże

3. Ludzie (zachowania, cechy charakteru, postawy cechy psychofizyczne)

4. Finanse

5. Emocje, uczucia

\section{Frazeologizmy w kontekstach dotyczących zdrowia, chorób}

Przegląd korespondencji prywatnej dowodzi, że Sienkiewicz cierpiał na wiele różnych schorzeń, wśród których znalazły się między innymi: wyczerpanie nerwowe (depresja),

${ }^{3} \mathrm{~W}$ zakres badań włączono również nielicznie reprezentowane przysłowia, które za Stanisławem B ą bą (1974: 385), Stanisławem S k o r u p k ą (1969: 221), Jolantą I g n a t o w i c z-S k o w r oń s k ą (2008: s. 16-17) zaliczam do podtypów związków frazeologicznych.

${ }^{4}$ Zob. przypis 1.

${ }^{5} \mathrm{Z}$ uwagi na obszerność bazy materiałowej w analizie uwzględniam tylko wybrane przykłady frazeologizmów. 
anemia mózgu, bezsenność, bronchit, nawracające infekcje górnych dróg oddechowych, chroniczne wrzody w gardle, chrypka, bóle artretyczne, umiejscowione w różnych częściach ciała, iszjas, bóle krzyża, lumbago, liczne newralgie, żółta febra, zaburzenia gastryczne o różnym charakterze, chroniczna bezsenność, a także choroby układu krążenia, arytmia, duszności, żylaki, i wiele innych (Zob. Mariak 2014, 2014a). Informacje na temat dolegliwości Sienkiewicz przekazywał głównie za pomocą nacechowanej ekspresywnie leksyki. Wśród frazeologizmów można wydzielić trzy grupy znaczeniowe, które określają:

1. Choroby, zły stan zdrowia, chorowanie, np.:

wyrażenia:

język pod psem: „Goraczki nie ma, ale język pod psem” (MB, 551 bez daty) (SF 1/673; pod psem) ${ }^{7}$, katar żoładka, kiszek: „Mam katar żoładka, a prawdopodobnie i kiszek” (JJ, 319/1892) (SF 2/894; katar żołądka), usposobienie lumbagowe (JJ, 1894, 384), usposobienia scyjatyczne (JJ, 388/1894) (SF 2/474; usposobienie jakie)

zwroty:

podkopać zdrowie, poderwać zdrowie, nerwy (JJ, 109/1888) (SF 2/815; poderwać zdrowie, podkopać zdrowie), stracić zdrowie (JJ, 493/1909) (SF 2/815; stracić zdrowie), nie mieć się dobrze (JJ, 1892, 307), mieć się gorzej (MB, 79/1903) / nieszczególnie (MB, 486/1911) / dosyć marnie (MB, 563 bez daty) (SF 1/441; mieć się dobrze, doskonale, nieźle), mieć żołądek, nerwy nie $w$ należytym porządku (MB, 103/1904) (SF 1/724; coś nie jest w porządku), ledwo dyszeć (MB, 162/1906) (SF 1/201; ledwo dyszeć), być chorym na głowę: „byłem chory ciagle na głowę” (JJ, 419/1895) (SF 1/136; chory na co), mieć bóle: „miewam ogromne bóle głowy” (JJ, 361/1894) (SF 1/110; mieć bóle czego), walczyć z gardłem: „Z gardłem walczę energicznie i myślę, że się wywinę z tej biedy” (JJ, 314/1892) (SF 2/502; SF 2/704: walczyć z czym; wywinąć się z biedy 'wyjść z tarapatów, wykręcić się'), klapnać na gardło: „Czuję, że gdybym został, klapnę znowu na gardło, więc wolę $w$ Wiedniu” (JJ, 403/1894) (SF 2/759: zapaść, zapadać na co 'zachorować na co'), źle sprawiać się z sercem: „Babunia zdrowa, ale Ciocia Dzinia zaczyna się znów jakoś źle sprawiać z sercem" (JS, 26/1908) (SF 2/184: sprawić się z czym)

frazy:

lumbago wlazło między topatki: „Moje lumbago lepiej, ale wlazło mi troche obecnie między topatki" (MB, 428/1911) (SF 2/581: coś wlazło komu w kości, nogę ...), Influenca poszła mi w piersi i żołądek (JJ, 368/1894) (SF 2/581: coś wlazło komu w kości, nogę ... itp.), nerwy potargaty się: „Nerwy moje potargały się do reszty i miewam ogromne bóle głowy" (JJ, 361/1894), nerwy targaja się gorzej i gorzej (JJ, 368/1894) (SF 1/494: targać

\footnotetext{
${ }^{6}$ W nawiasach podano inicjały adresatów listów, czyli: JHS - Henryk Józef Sienkiewicz - syn pisarza; JJ - Jadwiga Janczewska - szwagierka; JS Jadwiga Sienkiewiczówna - córka, MSz - Maria z Szetkiewiczów Sienkiewiczowa - pierwsza żona, MW - Maria z Wołodkowiczów Sienkiewiczowa - druga żona, MB - Maria z Babskich Sienkiewiczowa - trzecia żona; HS - Helena Sienkiewiczówna - siostra; natomiast liczby oznaczają odpowiednio: numer listu i rok jego powstania.

7 Zebrane frazeologizmy sprawdzono w (S k o r u p k a 1989, t. 1-2) (w skrócie SF).

${ }^{8}$ Lumbago 'silny ból w okolicy lędźwiowej kręgosłupa, najczęściej spowodowany zapaleniem korzonków nerwowych'; SW brak. Wyjaśnienia i komentarze pochodzą z przypisów dołączonych do listów zamieszczonych w zbiorze korespondencji prywatnej Sienkiewicza.

9 Scyjatyka 'choroba polegająca na zapaleniu nerwu kulszowego, inaczej ischias'; SW brak.
} 
nerwy), goraczka okropnie mnie zjadta (JJ, 403/1894) (SF 1/254: gorączka trawi kogo), nerwy i zdrowie psuja się (JJ, 403/1894) (SF 2/816: zdrowie czyje psuje się)

2. Zabiegi, badania medyczne, np.:

zwroty:

zaglądać w paszczę: „Chciat mi w paszczę zaglądać, ale mu powiedziałem: "Cura te ipsum» [<łac.> 'odczep się od duszy mojej' - L.M. ] (JJ, 49/1887) (SF 2/733: zaglądać komu w duszę, serce ...), oddać paszczę do reperacji: „Zębiska troche jeszcze dolegaja [...]. Na dobra sprawe wypadałoby zatrzymać się pare dni w Wiedniu - i oddać paszcze do reperacji (JJ, 87/1887) (SF 2/21: dać, oddać co do reperacji), oddać paszczę w opieke (komu): ,że zębiska (te, których nie ma) bola go to mniej, to więcej - i rad by, a raczej nierad by, ale musi oddać paszcze swoja w opieke Cybulskiemu [dentysta warszawski L.M.]" (JJ, 208/1890) (SF 1/605: oddać kogo w opiekę komu), mieć chrapkę na operację: „Heryng [warszawski laryngolog - L.M.] utrzymuje, że gdyby tylko wyciać migdały, nie wiedziałbym, co to ból gardła. Jeśli jednak ma chrapke na operację - to próżny apetyt" (JJ, 52/1887) (SF 1/137: mieć na co chrapkę), ząb pójdzie z interesu: „Zęby mnie pobolewaja i jeden pójdzie prawdopodobnie $w$ tych dniach «interesu»" (JJ, 488/1906) (SF 1/292: wyjść z interesu), chuchać, dmuchać: „Naturalnie, że będziemy na niego [syna - L.M.] chuchać, dmuchać, aby doprowadzić go do pożadanego stanu sił i zdrowia" (JJ, 466/1899) (SF 1/172: chuchać, dmuchać)

3. Zdrowie, brak dolegliwości, np.:

zwroty:

mieć się dobrze (JJ, 196/1899) / zupetnie dobrze (JJ, 481/1903) / nieźle (JJ, 255/1890) / lepiej (JJ, 395/1894) / doskonale (MB, 226/1907) (SF 1/441: mieć dobrze, doskonale, nieźle itp.), czuć się dobrze (JJ, 247/1890) / nieźle (JJ, 403/1894) / zdrowym (JJ, 489/1908) / zdrowszym (JJ, 261/1890), nie czuć się chorym (MB, 200/1906) (SF 1/156: czuć się dobrze, źle; czuć się zmęczonym, szczęśliwym itp.), pękać ze zdrowia (JJ, 255/1890) (SF 1/663: przen. pękać ze złości, ze śmiechu, z gniewu), trzymać się dobrze (MB, 364/1909) (SF 2/403: trzymać się dobrze), być w dobrym zdrowiu (MB, 98/1904) (SF 2/815: ktoś w dobrym zdrowiu), być w stanie kwitnacym (MB, 104/1904) (SF 2/203: w jakimś (dobrym, złym, beznadziejnym ...) stanie (z czasownikiem)), być dobrze z żoładkiem (JJ, 376/1894) (SF 1/124: być z kim dobrze/ źle), wyglądać tęgo (JJ, 265/1890) (SF 2/ 652: wyglądać zdrowo, dobrze ... itp.)

fraza:

zdrowie dopisuje (JJ, 439/1897) (SF 1/181: zdrowie dopisuje komu)

spetryfikowane konstrukcje porównawcze:

zdrowy jak smreczek (JJ, 174/1889), zdrów jak ryba (JJ, 412/1895), zdrowa jak wróbel (JJ, 363/1894), (SF 2/816: zdrowy /zdrów jak np. ryba, rzepa ... itp.), zdrów jak rydz (JJ, 466/1899); wygladać jak młoda rzodkiewka (MB, 192/1906), wyglądać jak samo zdrowie (JHS, 8/1906) (SF 2/653: wyglądać jak np. róża, rydz, samo zdrowie ... itp.)

4. Proces zdrowienia, np.:

przychodzić do siebie (HS, 25/1901) (SF 1/773: przyjść do siebie), przyjść do normy (MB, 66/1903) (SF 1/773: przyjść do równowagi), dojść do pięknego języka: „Gąssowski 
jest niezdrów na żoładek. [...] Ja również nie mogę dojść do pięknego języka" (MB, 125/1905) (SF 1/176: dojść do zdrowia).

Licznie reprezentowana grupa frazeologizmów wskazuje, że Sienkiewicz chętnie sięgał po ten środek wyrazu w opisie realiów związanych ze zdrowiem. Zróżnicowane pod względem semantycznym i formalnym związki (wyrażenia, zwroty, frazy) dzięki swym walorom obrazowym oraz potocznej proweniencji ${ }^{10}$ wzmacniały ekspresję i zrozumiałość przekazywanych treści. Prócz frazeologizmów w postaci kanonicznej, takich jak: katar żołąlka, pod psem, chuchać, dmuchać, poderwać zdrowie mamy formy zmodyfikowane. Wprowadzone przez Sienkiewicza innowacje służą ukonkretnianiu, precyzowaniu oraz aktualizacji informacji dotyczących zdrowia. Wśród odnotowanych przekształceń dominują innowacje wymieniające i rozwijające. Zwykle Sienkiewicz wprowadzał nacechowane zamienniki synonimiczne, np.: wlazło zam. weszło, klapnać zam. zapaść, do pięknego języka zam. do zdrowia.

Pod względem kryterium semantycznego (zob. SF Wstęp: 6) dominują frazeologizmy łączliwe. Konstrukcje tego typu umożliwiały Sienkiewiczowi tworzenie rozbudowanych ciągów synonimicznych, czasami o charakterze gradacyjnym, nazywających: chorobę, złe samopoczucie: nie mieć się dobrze, mieć się gorzej / nieszczególnie / dosyć marnie oraz zdrowie, dobre samopoczucie: mieć się dobrze / zupetnie dobrze / nieźle / lepiej / doskonale; czuć się dobrze / nieźle / zdrowym / zdrowszym, nie czuć się chorym.

Ponadto można przyjąć również, że częste użycie frazeologizmów w opisie różnych dolegliwości ma związek z dążeniem Sienkiewicza do omownego, eufemistycznego ujęcia tej sfery życia. Charakter i, jak to pisarz sam określił: „wersalskie usposobienie” (MB, 227/1890), „nie pozwalało mu szerzej mówić” o zbyt intymnych, wstydliwych lub prozaicznych szczegółach związanych z chorowaniem.

\section{Frazeologizmy w opisach podróży}

Sienkiewiczowskie opisy realiów związanych z podróżowaniem obfitują w środki wyrazu zaczerpnięte $\mathrm{z}$ ogólnej odmiany języka oraz formy nacechowane ekspresywnie, potoczne, których główną funkcją było aktualizowanie przekazywanych treści lub intensyfikowanie wartości emocjonalnej, np.: „W Rzymie krótko zabawię, bo go znam, $i$ pojadę jednym tchem do Wiednia, potem do Krakowa" (HS, 1/1886); ,puszczam kantem Warszawę" (MB, 280/1908); „Rawennę i Ferrarę zamierzam puścić kantem” (MB, 296/1908); „Podróż do Lowrany stoi mi kością w gardle, ale trzeba było to dla Małej zrobić." (MB, 357/1909), „uciekam, «gdzie pieprz rośnie», to jest do Włoch.” (JS, 31/1908); „Pokój mam dobry $w$ Rudolfshofie. Stoję pod własnym nazwiskiem." (HJS, 38/1906) (SF 2/493: pod przybranym nazwiskiem); ,panie Dzieduszyckie stoją w tym samym co $i$ ja hotelu" (MB, 3/1888); „Mateczka stanie w Krakowie na 20 bm.” (MB, 1906, 166) (SF 1/281: stanąć w hotelu ); „Ledwie dostałem numer w hotelu, bo i tu petno ludzi.” (MB, 151/1906) (SF 1/522: Wziąć, zajmować numer w hotelu).

10 Przyjmuję za Jerzym B artmińskim (1993: 118; 115-132) szerokie rozumienie potoczności: język potoczny, to język obiegowy, powszechny. W podobny sposób pojęcie to definiuje Teresa Sk ubalanka (1973: 180): język potoczny to język, mówiony, kolokwialny (język dialogów), nieoficjalny, ogólny (ogólnopolski), spontaniczny, szczególnie afektywny (ekspresywny). 
W relacjach z podróży stałym elementem były informacje na temat pogody. Zgromadzone związki frazeologiczne dowodzą, że podczas wielu krajowych i zagranicznych wypraw Sienkiewicz raczej nie miał szczęścia do dobrej pogody. W większości doniesień, nawet tych z krajów Europy południowej, pojawiają się informacje o deszczu, zimnie i braku słońca, np. „Czekamy ciepła i słońca jak kania dżdżu. Na Riwierze to przecie niestychana rzecz." (MB, 322/1909) (SF 1/316: Czekać, łaknąć czego jak kania dżdżu (deszczu) 'czekać czego niecierpliwie, bardzo pragnąć'); „Pogoda nie dopisuje $i$ ciagle jest zimno” (JJ, 183/1889); „Przyjechać do Włoch, żeby widzieć taka pogodę. Deszcz, zimno, ciemno, błotno, ponuro. I to już piąty, czy szósty dzień - a barometry jeszcze spadają" (JJ, 218/1890) (SF 1/ 95: Barometr spada 'wskazuje na niepogodę'); Wielka ochota bierze, żeby tu tego Miłego sprowadzić. Ale pogoda niżej wszelkiego pojęcia $i$ już tylko dwa tygodnie." (MB, 177/1906) (SF 1/361: Być, stać niżej wszelkiej krytyki 'nie mieć żadnej wartości'; SF 1/709: Coś przechodzi wszelkie pojęcie 'coś jest nieprawdopodobne'). Swoje zniecierpliwienie i rozczarowanie z powodu niesprzyjającej aury Sienkiewicz sygnalizował również za pomocą wyrażeń: pod psem (SF 1/673: 'niżej wszelkiej krytyki'), jak pies (SF 1/673: 'bardzo'). Związki te ze względu na dużą frekwencję i wielość różnych modyfikacji można zaliczyć do stałych elementów idiolektu pisarza, np.: „Do fiaska przyczynić się może i pogoda, która jest pod psem” (MB, 239/1908); „Janczewscy będa trochę odpoczywali na świeżym powietrzu, które jest aż nadto świeże, bo zimno $i$ deszcz pada. Czyż drugie z rzędu lato będzie pod psem?” (MB, 62/1903); „Dzień zimny jak pies. Rano na granicy pogoda i biaty szron, potem jeszcze zimniej” (MB, 237/1908); „Gorąco zresztą jak pies - i parno pomimo chwilowych deszczów" (MB, 114/1905) (SF 1/673). Oprócz wersji kanonicznej, Sienkiewicz wprowadzał liczne modyfikacje obu wyrażeń, które najczęściej polegały na zamianie leksemu pies na konkretne imię jednego z psów pisarza ${ }^{11}$, np.: „Aura, po włoskiej, wydaje się pod Wykopem” (JS, 30/1908); „A nie miatbym nic dlatego, że naprzód pogoda tu jest pod Wykopem. A po wtóre, że my wybieramy się do Krakowa” (HJS, 40/1907); „Niedziela. Pogoda pod Brysiem. Deszcz, wicher $i$ dziesięć stopni o jedenastej” (MB, 64/1903); „Tu pogoda nawet nie pod Brychem, ani Herbem, ale pod ostatnim oblęgorskim kundysem, Więc mimo woli wyobrażam sobie, że tak jest $i$ w Paryżu" (JS, 16/1908). Oprócz opisów aury zmodyfikowane formy wyrażeń pisarz stosował w ocenie innych realiów, np.: ,Kończę, bo pióra u pani Potworowskiej są niżej Wykopa” (MB, 47/1902); „Droge mialem pod wroną. Z powodu ukończenia manewrów pociag przepetniony” (JHS, 38/1906); „Chtopcy byli i mówia, że grano sztukę pod Tumanem, a szczególniej Mrozowska była niżej krytyki." (JS, 65/1913).

\section{Frazeologizmy w opisach ludzi}

Związki frazeologiczne określające osoby pełnią zwykle funkcję ekspresywną, uwydatniającą jakieś szczególne cechy wyglądu danej osoby, np.: „Chłędowski mizerny okropnie, do cienia podobny, zreszta zawsze byt chudy jak szczypka" (MB, 8/1884) (SF 1/37:

${ }^{11} \mathrm{~W}$ wielu listach do członków rodziny (zwłaszcza dzieci) zachowały się wzmianki o kilku psach oblęgorskich - Brysiu, Herbie, Wykopie, Tokaju, Trisorze (in. Tresie). (Zob. np. listy: HJS 19/1903; 20/1903; 40/1907 49/1908; JS 16/ 1908; 30/1908). 
chudy jak szczapa; SF 1/ 143: wyglądać jak cień ‘być mizernym, wychudzonym'); „Dzieci zastałem zdrowe. Dzinia piękna, przechodzi wszelką imaginację" (MB, 1/1888) (SF 2/673: coś przechodzi ludzkie, wszelkie wyobrażenie 'o czymś, co jest niezwykłe’); „Mówi, że Loewy jest hadki ${ }^{12}$ nad imaginację - a jednak byly panny, które znajdowały go przystojnym” (JJ, 71/1887) (SF 1/434: nad miarę, ponad miarę 'zbyt dużo, zbyt wiele'; SF 2/673: coś przechodzi ludzkie, wszelkie wyobrażenie 'o czymś, co jest niezwykłe'; SF 2/864: znaleźć kogo jakim). Grupa frazeologizmów opisujących wygląd zewnętrzny osób nie jest zbyt liczna. Z lektury całej zachowanej korespondencji prywatnej wynika, że Sienkiewicz znacznie chętniej w tej funkcji wykorzystywał inne środki wyrazu, np. epitety, nazwy apelatywne (przenośne i realnoznaczeniowe), nieskonwencjonalizowane porównania, metafory (zob. Mariak 2015; w druku). Znacznie bogatszy i bardziej zróżnicowany repertuar frazeologizmów odnosi się do opisu stanów psychicznych, cech charakteru oraz zachowania ludzi, np.: „Byłem wczoraj u p. Raczyńskiej, widziałem i jej siostre, p. Zamoyska. Obie są ścięte z nóg bardziej nawet, niżem się spodziewal" (MB, 244/1908) (SF 1/517-518: ściąć kogo z nóg 'pozbawić sił, osłabić'); „Pójdę z tym listem do skrzynki sam, bo Karol ma duszę na ramieniu” (HJS, 26/1905) (SF 1/194: mieć duszę na ramieniu 'bać się mocno'); „Marynia sieje odwagę. Wczoraj, gdy pisałem, przyszła pacierz zmówić w moim, gabinecie” (HJS, 26/1905) ( SF 2/108: siać co “szerzyć, powodować); „Wiem, że Cię język nie świerzbi $i$ że nie jesteś papla, można Ci tajemnicę, na której wielce zależy, powierzyć" (HJS, 31/1905) (SF 1/312: język kogo świerzbi, pali, piecze, swędzi 'ktoś nie może oprzeć się chęci mówienia, wygadania się z czym'); „Ulanowscy może by byli również nie pojechali, ale ona trzyma ich całkowicie pod pantoflem, co się z bliska lepiej widzi" (MB, 288/1908 (SF 1/646: trzymać kogo pod pantoflem 'narzucać komu swoją wolę, nie pozwalać na samodzielne decyzje'); „Oddałem czek Osuchowskiemu, który z radości przewrócil trzy lub cztery koziołki na sofie Benniego, następnie wykonat taniec dzikich" (MB,158/1906) (SF 1/704: wywijać kozły, koziołki, 'fikać kozły, koziołki; tu w zn. cieszyć się'; SF 2/346: dziki taniec); „Jutro jadę do Dzinki i przedstawię Twój projekt $i$ jej $i$ drowi Dtuskiemu, który zreszta stracil - zdaje się - te zludzenia, jakie mu przypisujesz" (HJS, 40/1907) (SF 2/851: Stracić złudzenia); ,gdyby nie to, iż wagony byty opalone, kłapałoby się zębami przez całą drogę" (JS, 27/1908) (SF 2/796-797: kłapać, dzwonić, szczękać zębami 'oznaka zmarznięcia'); „Bawia w Warszawie Żeromscy. Okcieńka wymyśla jakoby $w$ domu na «Dzieje grzechu», ale skacze do oczu, gdy robi to kto inny" (JS, 15/1908) (SF 2/117: skoczyć komu do oczu 'kłócić się z kim, mieć pretensje'); „O Kaziu opowiadają, że oddając po pojedynku pistolet, zatoczył się jak pijany, tak mu odwaga uderzyła widocznie do głowy" (MSz 10/1885) (SF 1/243: idzie, uderza do głowy [alkohol] 'odczuwa się działanie alkoholu'; SF 1/254: woda sodowa uderza komu do głowy 'ktoś staje się zarozumiały'; SF 1/679: Zachwiać się zatoczyć się jak pijany); „Mam aż nadto swojej roboty $i$ niczym na boku nie mogę się zajmować" (MB, 493/ 1911) (SF 1/108: zarabiać na boku 'dodatkowo'); Carl Wirsen ${ }^{13}$ kończy po francusku naturalnie niestychanymi pochwałami dla «Trylogii» «Bez dogmatu», «Rodziny Połanieckich», «Quo vadis», «Krzyżaków». Patrzę ukosem, jak pigułkę przełknie pruski ambasador, który sie-

12 SW, t. 2, s. 3: hadź<ukr. hadje> 'gady', przen. rzecz hadka, czyli brzydka'.

13 Carl Dawid Wirsen - szwedzki poeta, krytyk literacki wygłosił płomienne przemówienie na cześć Sienkiewicza podczas uroczystości wręczenia Nagrody Nobla. (Zob. przypis 7. do listu 147). 
dzi koło mnie - $i$ wpadam w dobry humor przy opisie Grunwaldu. Prusak zreszta ani drgnąl" (MB, 147/1905) (SF 2/445: patrzeć, spoglądać, zerkać ukosem 'ukradkiem, z niechęcią, nieprzyjaźnie'; SF 1/763: przełknąć [gorzką] pigułkę 'doznać jakiejś przykrości’; SF 1/282: wpaść, popaść w dobry /zły humor; SF 1/187: ani drgnąć 'nie poruszyć się, nie zmienić się'); „Ja przespałem kamiennym snem dziesięć godzin, ale może właśnie dlatego zmęczony jestem jak nieboskie stworzenie" (MB, 80/1903) (SF 2/100: kamienny sen; SF 2/239: jak nieboskie stworzenie 'bardzo, niezwykle, w najwyższym stopniu'); ,Ale czekamy Was bardzo z żurem, z podczosem ${ }^{14}$ i z otwartymi ramionami” (MB, 40/1902) (SF 1/152: przyjąć kogo z otwartymi ramionami 'serdecznie, chętnie, gościnnie'; SF 2/9: czekać kogo, czego 'spodziewać się kogo).

Wśród zebranych frazeologizmów, których Sienkiewicz użył w kontekście charakterystyki ludzi, znalazła się spora grupa połączeń pełniących głównie funkcję wartościującooceniającą, np.: „Chodzi o pomoc $i$ pośrednictwo kilku grubszego kalibru ugodowców w pewnej sprawie" (MB, 214/1906) (SF 1/314: przen. kto małego, wielkiego, ciężkiego kalibru 'małego, wielkiego znaczenia'); „Donióst mi także, o czym napisałem dzieciom, ̇̇e ciagle $w$ mieście i po wsiach jakieś spod ciemnej gwiazdy i nieznane figury dopytywaty się o nasz przyjazd do Oblęgorka" (MB, 187/1906) (SF 1/273: spod ciemnej gwiazdy "najgorszego gatunku, ostatni'); „Przyszedt do mnie Zdzisław Dmochowski z propozycja, bym się pozwolit wybrać na prezesa Towarzystwa Naukowego w Warszawie. Powiedziałem, że się porozumiem z Toba, lecz nie obiecuje. - Być malowanym prezesem nie chcę, a zajać się biegiem spraw nie mam czasu' (MB, 536/1913) (SF 1/418: malowany.... 'ktoś, kto nie ma przysługujących mu uprawnień, istniejący dla pozoru').

\section{Frazeologizmy w opisach kwestii finansowych}

Oprócz zdrowia i podróży do tematów często podejmowanych w korespondencji prywatnej Sienkiewicza należały finanse, zwłaszcza te związane z zapewnieniem bytu materialnego najbliższej rodzinie, a także innym krewnym ${ }^{15}$. W swoich listach Sienkiewicz systematycznie informował członków rodziny o różnych przedsięwzięciach, inwestycjach związanych nie tylko z funduszami rodzinnymi, honorariami, które otrzymywał od wydawców, ale także stypendiami, darowiznami przeznaczanymi na cele społeczne i działalność charytatywną. Fragmenty listów poświęcone finansom zwykle odznaczały się nacechowaniem emocjonalnym, na co wskazują użyte związki frazeologiczne, np.: „Heniowi dałem już poprzednio sto koron i ze skwapliwości, z jaka je « zagarnął», wnoszę, że istotnie przypominał świętych tureckich" (MB, 207/1907) (SF 2/406: goły jak święty turecki 'bardzo biedny; niemający grosza przy duszy’); „oto sprzedać ten zapisany mi obraz, a pieniadze

${ }^{14} \mathrm{SW}$, t. 4, s. 345: podczos 'potrawa przyrządzona z młodych najpierwszych liści kapusty'.

${ }^{15}$ Korespondencja prywatna Sienkiewicza zawiera wiele przykładów bezinteresownej troski pisarza o bliższych i dalszych krewnych, którym bez względu na sytuację zawsze „otwierał kredyt” (HS 50/1909). Z pomocą spieszył zwłaszcza dwóm siostrom Zofii i Anieli i ich rodzinom, np. łożył na wykształcenie siostrzeńców, fundował im stypendia i pomagał w karierze. Trzecią siostrę - Helenę - wyposażył, dzięki czemu mogła ona wstąpić do Zgromadzenia Sióstr Kanoniczek, ojcu wypłacał dożywotnio comiesięczną pensję. Ponadto w trosce o zdrowie członków swojej rodziny i innych krewnych, organizował i finansował wyjazdy nie tylko do polskich, ale również europejskich uzdrowisk. 
odesłać Witkiewiczowi, który jest mocno chory, a zapewne $i$ goły, jak grecki bożek" (MB, 258/1908) (SF jw.); „Mówiła Marynia, że chciała jechać zaraz z dworca do Oblęgor$k a$, ale nie miala grosza przy duszy, gdyż po drodze na Prage okradli ja $w$ tramwaju" (JJ, 73/1913) (SF 1/263: nie mieć grosza przy duszy 'nie mieć pieniędzy'); „Powiedz Maryni, że w papierach, które mi przywiózł do podpisania Kozakiewicz w sprawie «Quo vadis», nie wszystko mi się podoba $i$ niektórych stanowczo nie podpiszę. Te sumy neapolitańskie, jeśli choć część ich przyjdzie, to przyjda dopiero za pót roku lub i za rok" (JJ, 74/1913) (SF 2/244: sumy neapolitańskie 'ogromna ilość pieniędzy'; tu iron. o niewielkiej kwocie honorarium); „Oczywiście myśle pozwolić, by mnie naciagano tak bezczelnie - $i$ zlamanego grosza nie zobacza" (JJ, 82/1916) (SF 2/844: złamany grosz, szeląg 'drobna suma pieniędzy”); „Tymczasem „Słowo” wypłaca mi a conto listów 20000 franków, ja zaś zapowiedziałem z góry, że ze swoich pieniędzy nie poświęcę złamanego centa" (HS, 3/1890) (SF 2/844: złamany grosz, szeląg 'drobna suma pieniędzy'); „Bilety często odsytamy, ale trafiaja się takie, które trzeba przyjąć, a $i$ te robią pewne szczerby w kieszeni” (HJS, 65/1914) (SF 1/265: poczynić szczerby w czym 'poczynić szkody; śmierć'); „Abakanowicza znam od wieków Znałem go za jego złych czasów w kraju, gdy klepal biedę; bytem mu kilkakrotnie pożyteczny, zatem zrozumiesz, jak mi jest rad" (HS, 6/1894) (SF 1/100: cierpieć, klepać biedę 'żyć w niedostatku'); „Do Wandzi pisałem niedawno i za parę dni znów napiszę. Rad jestem, że Tetmajer dostanie stypendium. O ulicznikach ${ }^{16}$ Cio- $^{-}$ ci myślę, ale z próżnego i Salomon nie naleje" (JJ, 86/1916) (SF 2/89: przysł. Z pustego (próżnego) i Salomon nie naleje).

\section{Frazeologizmy w opisach uczuć i stanów emocjonalnych}

Ostania z wyróżnionych grup znaczeniowych zawiera frazeologizmy, które służyły Sienkiewiczowi do wyrażania własnych emocji, uczuć i ocen wobec opisywanych realiów. W tej funkcji pisarz wykorzystywał głównie nacechowaną ekspresywnie frazeologię o potocznej proweniencji, np.: „W Krakowie jest ogólne współczucie, a zarazem oburzenie na „Nowiny”, które rozlepity plakaty z tytułem: «Samobójstwo profesora Uniwersytetu». Ach! w pyski bić i patrzeć tylko, czy równo puchną!" ${ }^{17}$ (MB, 371 1910) (SF 1/785: żart. bić i patrzeć, czy równo puchnie 'zwrot wyrażający dezaprobatę czyjego postępowania'); „Do wściekłości doprowadza mnie to, że rozmaite baby, których oczywiście nie znam, zaczynaja mnie niepokoić o autografy. Uważam to za nieprzyzwoitość, za która powinno się w skórę bić” (MB, 463/1911) (SF 1/128: dać w skórę 'zbić kogo mocno'); „Jeśli dziennikarze będa przychodzili do Ciebie z prośba o moje listy, każ im się wypchać. Jest jedna rzecz doskonała $w$ naturze, to jest, że dzień, który się zacząt, musi się skończyć" (MB, 147/1905) (SF 2/388: posp. każ się wypchać trocinami 'zwrot wyrażający lekceważenie czyjejś propozycji'); ,dla mnie jest wszystkim Twoje zdrowie, $i$ wolatbym, żeby licho porwało pierwej wszystkie Oblęgorki, gdybyś przez nie miała nerwować się $i$ chorować"

${ }^{16} \mathrm{~W}$ związku z wybuchem wojny i mobilizacją ojców rodzin wiele dzieci i młodzieży zostało bez opieki. Zajął się nimi komitet społeczny, utworzony przy parafii Wszystkich Świętych. (Zob. przyp. 7 do listu 86).

17 Chodzi o podaną przez „Nowiny” nieprawdziwą informację o śmierci prof. anatomii UJ - Adama Bochenka, w istocie była to nieudana próba samobójcza (Zob. przypis 3 do listu 371). 
(MB, 296/1908) (SF 1/386: niech licho porwie 'przekleństwo, zwrot wyrażający zniecierpliwienie, gniew'); „Moses wspominat mi o jakimś liście czy przesytce, do której trzeba dopłacić sto rubli. Boję się tylko, czy to nie portret Boznańskiej. Ramy płaca jakoby ogromne cło. W takim razie niechże ją kaczki zdepczą" (JS, 74/1913) (SF 1/313: niech cię kaczki zdepczą 'wykrzyknienie oznaczające oburzenie, zniecierpliwienie'); ,robota to jedyna rozrywka i bez «Puszczy $i$ pustyni» chyba bym się wściekł z nudów” (JS, 56/1911) (SF 2/879: zwariować z czego); „Tylko to jest pewne, że $w$ dotychczasowych powieściach o Legionach z 1797 sa baliwerny ${ }^{18}$ wolające o pomstę do Boga" (MB, 494/1911) (SF 1/718: wołać o pomstę do Boga 'domagać się kary, pomszczenia'); „Telefonowała p. Mycielska z podziękowaniem za dobroć, następnie pp. Ejsmondowie, potem p. Gassowska, potem Osuchowski etc., etc. Wszystko to wystawia na ciężkie próby moją głuchotę - i drażni mnie" (MB, 532/ 1913) (SF 1/755: wystawić kogo, co na próbę 'doświadczyć kogo'). Do tej kategorii frazeologizmów można włączyć sporą grupę połączeń, które służyły uwypukleniu skali lub niezwykłości przedstawianych zjawisk, realiów czy osób, np.: „Tymczasem sesje, sesje, telefon, dzwonek $i$ korespondencja przechodząca wszelką miarę przyzwoitości” (JS, 8/1907) (SF 1/435: przechodzić miarę “przesadzić w czym'); „Sprawa ta jest zreszta skończona. Wyniesiono Osuchowskiego pod niebiosa, a nawymyślano Staweckiemu i nawymyślali wszyscy" (JS, 12/1908) (SF 1/499: wynosić, wychwalać pod niebiosa 'bardzo wychwalać, zachwycać się'); „Należy się dobrze zastanowić, czy prowadzić roboty, czy też może lepiej zaniechać wszystkiego - i zburzyć te przeklęta budę, która jest $i$ będzie wiecznie bezdenną studnią" (MB, 338/1909) (SF 2/238: bezdenna studnia 'o czymś, czego nie można zapełnić'); „Po drodze przejeżdżaliśmy takie ulice, o których się filozofom nie śniło. Byliśmy $w$ prawdziwym tureckim mieście, a raczej $w$ tureckich zaułkach" (JJ, 30/1886) (SF 1/221: o czym się filozofom nie śniło 'rzecz niebywała') oraz potoczne konstrukcje porównawcze, za pomocą których Sienkiewicz opisywał zjawiska, wydarzenia o charakterze nagłym, gwałtownym, np.: „Prócz Zośki i p. Delon przyjechało dwóch kolegów Henia, a wczoraj spadli jak piorun z niebios Curtinowie" (MB, 70/1903) (SF 2/165: spaść jak piorun z jasnego nieba 'nagle, niespodziewanie'); „Boję się, że Curtinowie spadną tu na mnie jak nawałnica lada dzień, razem ze swoimi aparatami fotograficznymi” (MB, 59/1903) (SF 2/165: spaść jak burza, huragan 'nagle, niespodziewanie'; spaść jak grad 'w dużej liczbie'); ,przysłała p. Michalska pieska. Byt mity, wszystkimi sie podobat przez swoja pieszczotliwość i wczoraj zdecht, ale tak nagle, jakby go piorun trafil' (MB, 117/1905) (SF 1/689: jakby go piorun raził 'nagle, niespodziewanie').

Przedstawiona klasyfikacja semantyczno-funkcjonalna wskazuje, że związki frazeologiczne są specyficznymi, wielofunkcyjnymi strukturami językowi, bardzo przydatnymi w komunikacji listownej. Dzięki nim Sienkiewicz - nadawca komunikatu - mógł równocześnie informować, wyrażać swoje emocje, oceniać oraz zaznaczać swój stosunek do opisywanej rzeczywistości.

Pod względem formalno-strukturalnym w zgromadzonym materiale również można zaobserwować wiele ważnych i ciekawych zjawisk. Konfrontacja zebranego materiału ze Słownikami frazeologicznymi (Skorupka 1986; Galle, Krasnowolski 1928) wykazała, że Sienkiewicz równie często wykorzystywał zarówno formy kanoniczne, jak i zmodyfikowane postacie frazeologizmów. Wśród pierwszej kategorii grupy znalazły się głównie zwroty

18 Baliwerny <fr. la baliverne >'niedorzeczności'; SW brak (zob. przypis 4 do listu 494). 
nazywające czynności lub stany, np.: zniknać jak kamfora: „Oddawca Twego listu zniknąl jak kamfora, a ponieważ posłańców z powodu święta nie było, więc nie mogłem Ci zaraz odpisać" (MB, 13/1896) (SF 1/315: zniknąć, ulotnić się, przepaść jak kamfora 'zniknąć niepostrzeżenie'); rozegnać na cztery wiatry: „Słowa: «Sprawa z woda załatwiona», znacza, że była wielka bitwa morska i że flotę rosyjska nieubłagany Togo wraz z Uriu $i$ Kanimura rozegnali na cztery wiatry" (MB, 110/1905) (SF 2/539: rozegnać na cztery wiatry 'przepędzić gwałtownie, bezwzględnie, na zawsze'); skręcić kark: „Byłoby bardzo nieprzyjemnie i bezpożytecznie skręcić kark po drodze lub nawet stanać z musu na jakiejś marnej stacji” (MB, 122/1905) (SF 1/318: skręcić złamać kark 'zrobić sobie krzywdę, zabić się, doznać niepowodzenia'); położyć uszy po sobie: „Rusini pobici sromotnie $w$ debacie parlamentarnej w Wiedniu zamierzają na pewien czas położyć uszy po sobie” (MB, 270/1908) (SF 2/419: kłaść, położyć (po sobie) uszy 'stawać się pokornym, potulnym; tchórzyć'); zasnać jak kamień: „w goraczce nie można zbyt twardo spać, a ja zasnąłem jak kamień” (MB, 395/1910) (SF 2/779: zasnąć jak kamień 'mocno'); mieć duszę na ramieniu: „Pójdę $z$ tym listem do skrzynki sam, bo Karol ma duszę na ramieniu” (HJS, 26/1905) (SF 1/194: mieć duszę na ramieniu 'bać się mocno'); położyć trupem: ,Marynia obawiała się, że tam polożą mnie trupem Rusini, których podejrzewa o rozesłanie zbójców do wszystkich miast i części świata" (JS, 27/1908) (SF 2/393: położyć, powalić, rozciągnąć kogo trupem 'zabić, zadźgać, zastrzelić kogo'); wziąć rozbrat: „Henio wziąl rozbrat z Wawelem ${ }^{19}$. W ogóle milczy, ale coś o tym bąknąt" (JS, 67/1913) (SF 2/44: wziąć, uczynić z kim, z czym rozbrat 'zerwać, zaprzestać czego'); pociagnać za język: „Przypuszczam, że Zaleski nic dobrze nie wiedziat $i$ że jako dyplomata starał się pociągnąć za język Potkańskiego" (MW, 3/1893) (SF 1/312: pociągnąć kogo za język) i inne. Duże nasycenie listów spetryfikowanymi połączeniami słownymi zastępującymi formy czasownikowe jest cechą charakterystyczną języka potocznego (Buttler 1977:153). Listy, jak zostało to powiedziane wcześniej, są środkiem przekazu zbliżonym do komunikacji ustnej, rodzajem rozmowy „na odległość” (Data 1989:146), dlatego obecność środków wyrazu właściwych tej odmianie języka jest zjawiskiem naturalnym.

W grupie frazeologizmów niekanonicznych występują wszystkie typy modyfikacji, a więc regulacja, rozwinięcie, wymiana, kontaminacja (Bąba 1989). Można tu również wskazać przykłady modyfikacji o charakterze mieszanym:

- innowacje regulujące, np.: obie są ścięte z nóg (SF 1/517-518: ściąć kogo z nóg 'pozbawić sił, osłabić'); w słomianym wdowieństwie (SF 2/522: żart. słomiana wdowa); wagony zimne jak psiarnie (SF 2/837: zimno jak w psiarni 'bardzo zimno'); łam sobie główkę (SF 1/243: łamać sobie głowę 'kłopotać się czym'), błędne kółko (SF 1/105: błędne koło 'przen. sytuacja bez wyjścia'),

- innowacje skracające, np.: każ im się wypchać (SF 2/388: każ się wypchać trocinami); słowo się rzekło (SF 2/147: słowo się rzekło, kobyłka u płotu),

- innowacje rozwijające, np.: „,wszystkie przeszkody spod Twoich najdroższych $i$ ukochanych nóżek usunąć (SF 1/768: usunąć przeszkody); mocno przyciskać go do muru (SF 1/462: przyciskać kogo do muru 'być zmuszonym okolicznościami do czego'); honory domu robi $z$ wdziękiem (SF 1/280: robić honory domu); trzyma ich calkowicie pod panto-

19 Henryk Józef wykonywał prace konserwatorskie na Wawelu, ale z pracy zrezygnował, ponieważ nie zgadzał się z koncepcją odbudowy Zamku. (Zob. przyp. 3 do listu 67). 
flem (SF 1/646: trzymać kogo pod pantoflem 'narzucać komu swoją wolę'); wystawia na ciężka próbę moja gluchotę (SF 1/755: wystawiać kogo, co na próbę); przejść nad ta sprawa do porządku, a raczej nieporządku dziennego (SF 1/724: przejść nad czym do porządku <dziennego>'pominąć, zignorować co'); ucieka, gdzie pieprz rośnie, czyli do Włoch (SF 1/669: uciekać, gdzie pieprz rośnie 'daleko, jak najdalej'); prawdziwy bukiet czarnych myśli (SF 1/150: czarne myśli); Marek rozpuścit się do reszty jak dziadowski bicz (SF 1/99: rozpuścić się jak dziadowski bicz 'stać się niesfornym; rozpieścić kogo'). W przypadku ostatniego z frazeologizmów mamy do czynienia z ciekawym przykładem rozwinięcia związku członem, który również jest frazeologizmem: do reszty 'do ostatka, doszczętnie, zupełnie, całkowicie' (SF 2/22: do reszty),

- innowacje wymieniające, np.: chudy jak szczypka (SF 1/137: chudy jak szczapa), pod Brysiem, pod Wykopem, pod wrona (SF 1/673; pod psem); kuć żelazo zbyt gorace (SF 2/894: kuć żelazo póki gorące 'korzystać z nadarzającej się okazji'); jakby go piorun trafit (SF 1/689: jakby go piorun raził 'nagle, niespodziewanie'); ale to były oczywiście zbyteczne grzyby w barszcz (SF 1/96: dwa grzyby w barszcz 'zbyteczne nagromadzenie tych samych rzeczy'); głaszcze po makówie (SF 1/238: głaskać po głowie); grubszego kalibru ugodowcy (SF 1/314: przen. kto małego, wielkiego, ciężkiego kalibru 'małego, wielkiego znaczenia'); na łonie macierzyńskim (SF 1/408: na łonie rodziny 'wśród rodziny'); powinno się w skórę bić (SF 2/128: dać w skórę 'zbić kogo mocno'); nie oddam tego listu za konia z rzędem, ani za sikawkę ogrodowa, ani za wyżła... (SF 2/119: nie uczynić, nie zrobić czego za skarby świata 'za nic'). Jednym z komponentów wymiany w tej innowacji jest frazeologizm konia z rzędem temu, kto.... 'ktoś zostanie sowicie nagrodzony za włożony trud'),

- kontaminacje, np.: ostrzę zęby i język na tego Biednego. Jest to kontaminacja z węzłem formalnym „ostrzyć” i węzłem semantycznym 'szykować się na dokuczenie komu', co wynika z połączenia trzech podstaw kontaminacyjnych, bliskich semantycznie (SF 1/312: ostrzyć sobie język na kogo 'szykować się na polemikę z kim, na drwinki z kogo'; SF 2/796: ostrzyć sobie zęby na co 'szykować się do krytyki, dokuczenia komu'; SF 2/796: ostrzyć sobie zęby na kim 'dokuczać komu, krytykować, obmawiać kogoś',

- modyfikacje mieszane:

wymiana + regulacja, + skrócenie, np.: schować się jak myszy pod miottę (SF 1/463: siedzieć cicho jak mysz pod miotłą; modyfikacja wymieniająca (schować $\rightarrow$ siedzieć), regulująca (mysz $\rightarrow$ myszy; pod miotłą $\rightarrow$ pod miotłę; ucięcie $\rightarrow$ cicho),

wymiana + rozwinięcie, np.: przewrócit trzy lub cztery koziotki na sofie Benniego (SF 2/704: wywijać koziołki; wywijać $\rightarrow$ przewrócić + trzy lub cztery, na sofie Benniego ); wypuścitbym na nia jowiszowe gromy (SF 1/263: rzucać gromy na kogo) (rzucać $\rightarrow$ na wypuścić + jowiszowe),

rozwinięcie + regulacja, np.: wybieramy się tymczasem ciagle jak sójki za morze (SF 2/163: przysł. Wybiera się jak sójka za morze).

Przekształcenia związków frazeologicznych służyły głównie aktualizacji i konkretyzowaniu przekazywanych informacji, a także intensyfikowaniu ich wartości ekspresywnej. Ponadto celem Sienkiewicza była chęć przedstawienia treści w sposób humorystyczny, żartobliwy oraz rozweselenie adresatów listów. Sienkiewicz bardzo lubił żartować i miał duże poczucie humoru, o czym wiemy z przekazów potomnych, pośrednio również z lektury jego utworów. (Zob. Świętosławska 1996; Wilkoń 1976; Listy 1996: t. 2. Cz. 1; Wstęp: 102-104). Przykłady żartobliwych przekształceń stałych związków frazeologicznych są 
dość częste. Efekt humorystyczny uzyskiwał Sienkiewicz dzięki zmianie tradycyjnego składu słownego lub struktury połączenia, czego efektem był kontrast między treścią lub zabarwieniem tradycyjnego związku, a sensem lub barwą jego zmodyfikowanego odpowiednika (Buttler, 1974: 139-140.). Zabiegi kompozycyjne Sienkiewicza polegały głównie na degradacji podniosłej treści frazeologizmu, np. dzięki kontekstowi (podniosły frazeologizm w strywializowanym kontekście) i/ lub zmianę składu leksykalnego (rozwinięcie związku, zamiana członów nienacechowanych na nacechowane), np.: „Hering, specjalny laryngista, jest także ciężko chory na gardziel i jedzie do Palermo. Chciat mi w paszcze zaglądać, ale mu powiedziałem: "Cura te ipsum » $i$ odczep się od duszy mojej!" (JJ, 49/1887) (SF 2/379: przysł. Lekarzu, uzdrów samego siebie <łac. Medice, cura te ipsum>); „Habemus nareszcie papam, to jest mamy postów. Szkoda, że nie lepszych, że nie głębszych, że nie zdolniejszych, ale przynajmniej Polaków" (HJS, 34/1906) (SF brak; SWOK, s. 166: Słowa obwieszczające ludowi wybór nowego papieża, <łac. 'Mamy papieża’>); „Na naszej ulicy jest pani [...] mająca mizerna dwunastoletnia córkę, której potrzeba wsi. Otóż szturmowała ona do mnie [...]. Teraz szturmuje do Maryni, która już u niej była [...]. Rezultat, że ta córka powiększy zapewne grono aniołków już egzystujacych w Oblęgorku" (HJS, 24/1904) (SF 1/87: powiększyć grono aniołków 'o dzieciach umrzeć'); „Twoja siostra telepie za dwoje, a nawet za troje. Pomaga jej $w$ tym dzielna Zosia” (HJS, 9/1902) (SF 1/196: wykonywać jakąś czynność za dwóch 'tu dużo mówić'); „Wolff jednak spodziewat się zamknięcia i miat w kieszeni druga koncesję. Ponieważ uszło mu na sucho, więc zapewne stanie się jeszcze zuchwalszy $i$ «przypłaci to głową lub czymś podobnym takim»" (JS, 11/1908) (SF 1/779: przypłacić co życiem 'ponieść śmierć'). Komizm ostatniego zwrotu można umotywować dwojako, w zależności od interpretacji znaczenia członu rozwijającego - lub czymś podobnym takim. W pierwszym przypadku rozwinięcie można potraktować jako eufemizm nazywający pośladki, dolną część ciała, w drugim - jako coś bliżej niesprecyzowanego, co w połączeniu ze znaczeniem kanonicznej postaci frazeologizmu narzuca całej konstrukcji absurdalną treść.

Funkcję humorystyczną można również przypisać kilku frazom zręcznie wplecionym w treść listu napisanego 14 października 1909 roku do Jadwigi Janczewskiej z okazji jej imienin. W liście tym pisarz składa solenizantce ,najlepsze życzenia, wedle przysłowia, które mówi: «Gdy dobre życzenia, Pan Bóg ich nie zmienia». Oby, jeśli się co ma zmieniać, zmieniało się tylko na lepsze. Ale że inne przysłowie znów mówi: «Temu żywot mily, kto ma czerstwe siły», więc życzę Ci sit przede wszystkim. Dobrze zrobiłaś, żeś się wybrata $z$ Opacji, gdyż stara to jest prawda, iż: «Gdy wola Boża, trzeba i do morza». Mam też nadzieję, że Ci to postuży, bo choć jedno przystowie mówi: «Kto się za dużo spodziewa, $\mathbf{z}$ tego się diabel wyśmiewa» - to za to drugie odpowiada: «Rozumnej nadzieje wiater nie rozwieje». Siedź więc, lecz się $i$ wracaj nie tylko zdrowo, ale $i$ z miła chęcia w myśl przysłowia: «Odbiegnie kołaca, kto do domu wraca». Jeśli wrócisz na święta, to się możemy, jeśli Bóg pozwoli, zjechać w Krakowie, gdyż to już przecie w Polsce powtarzano: «Gościniec krakowski wiedzie z każdej wioski» itd. Warto odnotować, że wskazane w tym cytacie frazy, które Sienkiewicz określił mianem przysłów, prawdopodobnie są dziełem jego inwencji twórczej. Żadna z form nie została bowiem odnotowana w źródłach paremiograficznych, słownikach frazeologicznych (Krzyżanowski (red.) 1970; Skorupka 1989; Galle, Krasnowolski 1928), słownikach ogólnych języka polskiego (SJPD, SW) ani w słownikach pisarzy (Górski, Hrabec (red.) 1962-1983; Koneczna, Doroszewski 1965). 
Warto podkreślić, że Sienkiewicz nadał tym konstrukcjom zgodną z wzorcem postać i zastosował w funkcji charakterystycznej dla paremii (wszystkie są zrytmizowanymi zdaniami, utworzonymi na zasadzie paralelizmu, pełniącymi funkcję stwierdzeń lub pouczeń, odnoszącymi się do konkretnej sytuacji życiowej), co nadaje im walor autentyczności. (Zob. Sławiński (red.) 1988: 412; hasło: Przysłowie).

Na zakończenie podjętych tu rozważań warto poświęcić kilka słów usytuowaniu listów Sienkiewicza w obrębie poszczególnych sfer komunikacji. Z uwagi na cechy funkcjonalne i genologiczne list prywatny, jest tekstem wyjątkowym, bowiem łączy w sobie cechy właściwe gatunkom pisanym (dystans czasowy i przestrzenny, ustalona struktura) i mówionym (funkcja pragmatyczna, interakcja, środki językowe) (Data 1989: 142-145; Bartmiński, Niebrzegowska-Bartmińska 2009: 98). Badania treści, struktury i środków językowych listów prywatnych Sienkiewicza wskazują, że codzienną korespondencję z najbliższymi pisarz traktował jako substytut rozmowy o charakterze osobistym (Data 1989: 146). Dominacja funkcji użytkowej, pragmatycznej nad estetyczną, literacką przejawia się m.in. w użyciu środków językowych przynależnych do odmiany potocznej ${ }^{20}$. Jeśli chodzi o frazeologizmy, to warto zaznaczyć, że z wyjątkiem kilku, wszystkie należą do odmiany potocznej średniego poziomu, nie ma wśród nich np. form wulgarnych. Związki typu: klepać biedę, kłapać zębami, puścić kantem, jak Pan Bóg stworzyt, zniknać jak kamfora, skręcić kark, położyć krzyżyk, jeść ile wlezie, boki zrywać, ledwo zipać, przewracać koziołki, przyjść na myśl, chodzi po głowie, przyszło co do czego, język świerzbi najlepiej służyły komunikacji nieoficjalnej, dzięki nim pisarz w sposób konkretny, naturalny przekazywał rodzinie informacje związane z życiem codziennym. Poza tym frazeologizmy tego typu dynamizowały zwykle monotonny relacyjny, opisowy charakter przekazu listowego.

Frazeologia stylu wysokiego, o proweniencji biblijnej, mitologicznej, literackiej jest reprezentowana zaledwie przez kilka przykładów: wychylić kielich goryczy, płacz i zgrzytnie zębów; Augiaszowa stajnia / stajnia Augiasza, Madejowe łoże.

\section{Podsumowanie}

1. Frazeologizmy zawarte w korespondencji prywatnej Sienkiewicza są ważnym środkiem językowej komunikacji, służącym wyrażaniu emocji, aktualizowaniu, precyzacji i konkretyzacji przekazywanych treści, dotyczących zwłaszcza zdrowia, podróży, finansów, charakterystyki ludzi, a także ocen i wartościowaniu przedstawianych realiów.

2. Dzięki frazeologizmom o potocznej proweniencji, powszechnie znanym i używanym tworzona przez Sienkiewicza korespondencja charakteryzowała się komunikatywnością, jasnością i obrazowością. Pomimo upływu czasu treść listów jest zrozumiała dla współczesnego odbiorcy.

3. Z przedstawionych w niniejszym szkicu konstatacji można wysnuć wniosek, że związki frazeologiczne w kanonicznej i zmodyfikowanej postaci należą do stałych i ważnych komponentów idiolektu Sienkiewicza. Preferencje i wyraźne upodobania Sienkiewi-

20 Pod względem doboru środków językowych i stylistycznych korespondencja Sienkiewicza realizuje wszystkie wyróżnione przez J. B artmińs ki e g o (1993: 120-124) typy rejestrów potoczności (neutralny : emocjonalny; swobodny : staranny), ale z przewagą cech charakterystycznych dla rejestru emocjonalnego i starannego. (Zob. również B ańk o w ska, Mik ołajczuk 2003: 72). 
cza w kwestii doboru frazeologizmów ujawniają pewną cechę charakterologiczną pisarza. $\mathrm{Z}$ dużą dozą prawdopodobieństwa można przyjąć, że Sienkiewicz prywatnie był człowiekiem wrażliwym, troskliwym, obdarzonym poczuciem humoru, który również poza sferą twórczości typowo artystycznej był estetą językowym, świadomie unikającym form z niskiego rejestru językowego, nielicujących z osobą adresata, ale także jego kulturą osobistą.

\section{Bibliografia}

B ań k ow ska Edyta, Mi k oła j c z u Agnieszka, 2003, Praktyczna stylistyka, Warszawa.

B artmiński Jerzy, 1993, Styl potoczny, [w:] B artmiński Jerzy, (red.), Wspótczesny język polski, Wrocław, s. 115-135.

B artmiński Jerzy, Ni ebrzegowska-Bartmińska Stanisława, 2009, Tekstologia, Warszawa.

B ą b a Stanisław, 1974, W sprawie klasyfikacji polskich jednostek frazeologicznych (zwrot szeregowy, zwrot rymowany), „Prace Filologiczne” XXV, s. 377-385.

B ą b a Stanisław, 1989, Innowacje frazeologiczne współczesnej polszczyzny, Poznań.

B u t t l e r Danuta, 1974, Polski dowcip językowy, Warszawa.

B u t 1 l e r Danuta, 1977, Polskie stownictwo potoczne. III Charakterystyka leksykalno-semantyczna zasobu słownikowego, „Poradnik Językowy”, z. 3-4, s. 153-163.

D a t a Krystyna, 1989, Struktura tekstu listowego, „Język Polski” LXIX, z. 3-5, s. 142-152.

G a 11 e Henryk, Krasnowolski Antoni, 1928, Stownik frazeologiczny, Warszawa.

Górki Konrad, H r a be c Stefan (red.), 1962-1983, Słownik języka Adama Mickiewicza, Wrocław, t. $1-11$.

Henryk Sienkiewicz, Listy. Tom 2.

Część pierwsza: Jadwiga i Edward Janczewscy, oprac. M. Bokszczanin, Warszawa 1996; Tom 2. Część druga: Jadwiga i Edward Janczewscy, oprac. M. Bokszczanin, Warszawa 1996; Tom 2.

Część trzecia: Jadwiga i Edward Janczewscy, oprac. M. Bokszczanin, Warszawa 1996; Tom 4.

Część pierwsza: Maria z Szetkiewiczów Sienkiewiczowa - Maria z Wołodkowiczów Sienkiewiczowa - Maria z Babskich Sienkiewiczowa (1888-1907), oprac. M. Bokszczanin, Warszawa 2008; Tom 4.

Część druga: Maria z Babskich Sienkiewiczowa (1908-1913), oprac. M. Bokszczanin, Warszawa 2008; Tom 4. Część trzecia: Henryk Józef Sienkiewicz - Jadwiga Sienkiewiczówna - Helena Sienkiewiczówna - Lucjan Sieńkiewicz, oprac. M. Bokszczanin, Warszawa 2008.

I g n a t o w i c z-Sk ow rońs k a Jolanta, 2008, Frazeologizmy jako tworzywo stylu współczesnej powieści polskiej, Szczecin.

K o n e c z n a Hanna, D o r o s ze w s k i Witold (red.), 1965, Stownik języka Jana Chryzostoma Pas$k a$, Wrocław - Warszawa - Kraków, t. 1-2.

Krzy ża now s k i Julian (red.), 1970, Nowa księga przysłów i wyrażeń przysłowiowych polskich, Warszawa, t. 1-4.

L a l e w i c z Janusz, 1975, Komunikacja językowa i literatura, Wrocław.

L e w i ck i Andrzej Maria, Pajdzińska Anna, 1993, Frazeologia, [w:] Jerzy Bartmiński, (red.), Encyklopedia kultury polskiej XX wieku, Wrocław, t. 2, s. 307-327.

Maria k Leonarda, „Żaba” $i$ „,Mgła” - językowy wizerunek Jadwigi Janczewskiej na podstawie listów prywatnych Henryka Sienkiewicza (cechy fizyczne) [w druku].

Mariak Leonarda, 2014, Funkcja ekspresywna leksyki z zakresu medycyny $w$ listach prywatnych Henryka Sienkiewicza, „Poznańskie Studia Polonistyczne. Seria Językoznawcza”, t. 21 (41), z. 2, s. 53-71. 
M a r i a k Leonarda, 2014a, Funkcja informacyjna leksyki z zakresu medycyny $w$ listach prywatnych Henryka Sienkiewicza, [w:] Małgorzata Gębka-Wolak, Joanna Kamper-Warejko, Andrzej Moroz, (red.), Leksyka języków stowiańskich $w$ badaniach synchronicznych $i$ diachronicznych, Toruń, s. 217-241.

M a ri a k Leonarda, 2015, „Żaba” i „,Mgła” - językowy wizerunek Jadwigi Janczewskiej na podstawie listów prywatnych Henryka Sienkiewicza (cechy charakteru, postawy), [w:] M a r i a k Leonarda, Rychter Joanna (red.), Współczesny $i$ dawny obraz kobiety w języku i literaturze, Szczecin, s. 181-191.

SF: S k o r u p k a Stanisław, 1989, Słownik frazeologiczny języka polskiego, Warszawa, t. 1-2.

SJPD: D o r o s z e w s k i Witold, (red.), 1958-1969, Słownik języka polskiego, Warszawa, t. 1-11.

S k o r u p k a Stanisław, 1969, Podstawy klasyfikacji jednostek frazeologicznych, „Prace Filologiczne", t. 19, s. 219-226.

S kubal a n k a Teresa, 1973, Ekspresywność języka a mowa potoczna, [w:] Stefania Skwarc z y ń s k a (red.), Poetyka i stylistyka słowiańska, Wrocław, s. 177-183.

Sła w ińs k i Janusz (red.), 1988, Stownik terminów literackich, Wrocław - Warszawa - Kraków - Gdańsk - Łódź.

SW: Karłowicz Jan, Kryński Adam, Niedźwiedzki Władysław, 1900-1927, Słownik języka polskiego, Warszawa, t. 1-8.

SWOK: K o palińs ki Władysław, 1985, Stownik wyrazów obcych i zwrotów obcojęzycznych, Warszawa.

Św ięt o sław ska Teresa, 1996, O stylu językowym Zagłoby w „Ogniem i mieczem” (w 110 rocznice Sienkiewiczowskiego arcydzieta), „Acta Universitatis Lodziensis. Folia Linguistica”, nr 35, s. 29-37.

Wil k oń Aleksander, 1976, O języku i stylu „Ogniem i mieczem” Henryka Sienkiewicza. Studia nad tekstem, „Zeszyty Naukowe UJ 427 Prace Językoznawcze”, z. 50, Kraków.

Z gółk ow i e Halina i Tadeusz, 1993, Językowy savoir-vivre, Poznań.

\section{LEONARDA MARIAK}

\section{Collocations in Henryk Sienkiewicz's private correspondence}

\section{Summary}

Key words: private letter, phraseology, stylistic phenomena, idiolect, Sienkiewicz

This article contains an analysis of structure, form and function of collocations included in 1400 Henryk Sienkiewicz's private letters.

The wide collection of over 450 collocations creates five semantic categories: health, travelling, finances, people (appearance, behaviour), feelings and emotions. In formal and structural terms the collected material contains collocations in canonical and modified form.

Keywords: private letter, phraseology, stylistic phenomena, idiolect, Sienkiewicz 